\title{
Driving Forces of Employees' Entrepreneurial Intentions - Leadership Style and Organizational Structure
}

DOI: 10.7595/management.fon.2019.0020

- Abstract:

Research Question: The purpose of this paper is to explore how leadership style and organizational structure characteristics influence employees' intentions to start their own entrepreneurial ventures, ideas or projects, within an organizational setting. Motivation: The main goal is to learn how to prevent innovativeness declining in a traditional organization and make internal environment friendly for entrepreneurial initiatives and for employees with propensity to develop new ideas, aiming to create sustainable competitive position. Idea: The paper explores how identified leadership variables, initiative, pioneer, proactive behaviour and ability to communicate vision affect employees' entrepreneurial intentions. We also analyze the organizational structure impact, testing organic design, level of centralization and formalization. For measuring employees' entrepreneurial intentions, we use a previously validated scale and measurements, innovation, risk propensity and autonomy. Data: The data are collected using a questionnaire on a random sample of 208 respondents employed in nineteen Serbian companies. Tools: A quantitative study methodology was designed and implemented, appropriate statistical methods performed, including correlation and linear regression analyses. Findings: We have found evidence that appropriate leadership style has a positive influence on employees' entrepreneurial intentions. More specifically, there is a positive correlation between the leader's initiative, pioneer and proactive behaviour, and the employees' intentions to start innovative entrepreneurial ventures. The employees' willingness to act autonomously is affected by leader's initiative and proactive attitude, but also by ability to clearly communicate the vision. The study also reveals that organic organizational structure, decentralization and low formalization have a positive influence on employees' entrepreneurial intentions. Contribution: The study contributes to a significant degree by filling gaps in knowledge base, revealing new perspectives about relevance of both leadership style and organizational structure for encouraging organizational entrepreneurship. The analysis also provides a more fine-grained perspective about characteristics of organizational design and improves understanding of the employees' actions depending on authority delegation, procedures and overall flexibility of organizational structure. Practical implications represent guidelines for practitioners as to how to set up structure and adjust leadership style in order to foster entrepreneurship among employees.

Keywords: Entrepreneurship, leadership, organizational structure, employees' entrepreneurial intention

JEL Classification: L26, D23, M13, O31, P23

\section{Introduction}

In the entrepreneurial organization, new ideas and projects are initiated by individuals, but leaders take responsibility for the emerging initiatives and encouraging innovations that create new value. Traditionally managed companies tend to grow at a moderate pace, without compromising current activities, risking resources or jeopardizing current managerial positions and structure. One of the biggest challenges for entrepreneurial leaders is how to embrace the latent conflict in the organization, and balance market validated and successful ongoing operations with unproven innovations, disturbing embedded patterns and bring discomfort, but aiming to secure a long term competitiveness. Companies emerge as innovative and unstructured new ventures, but growth eventually results in increased formalization, more rigid organizational 
structure, while the leadership style is getting more conservative and short-term oriented. The need for entrepreneurial initiative gets stronger, but the entrepreneurial intensity is declining.

Researchers are shifting focus from entrepreneurship as an individual initiative leading to development of new business towards entrepreneurship as a means of organizational growth and strategic renewal, initiated by employees within established companies. It is imperative to revive the entrepreneurial spirit by adapting the leadership style and creating a more flexible organization.

As organizational entrepreneurship is still a nascent field of research, relatively few studies in the past addressed the issue of organizational prerequisites for encouraging entrepreneurial behaviour (Kelley, 2011; Sebora et al., 2010; Srivastava and Agrawal, 2010; Goffin and Mitchell, 2010). Entrepreneurship in general, and especially organizational one, is a complex and dynamic process, based on a sequence of structural and management preconditions, and as such requires further investigation. However, so far, previous studies have been mainly descriptive, lacking empirical evidence, with insufficient conceptual foundation. Some researchers note that a traditional organization should be redesigned towards more organic, flexible, informal and decentralized structure, with new leadership style, capable of motivating and empowering employees to become entrepreneurs themselves (Martin-Rojas et al., 2011; Bhattacharyya, 2006). Even though numerous studies have addressed leadership style and organizational structure as part of management studies separately from each other, a gap still exists in the field of organizational entrepreneurship, particularly referring to the impact these factors might have on employees' entrepreneurial intentions, which is the main reason for initiating our research.

The paper is structured as follows. First, e conceptual model and theoretical considerations are provided based on a relevant literature review. Second, the research design, methods, measures and sample are described. Next, the results are presented, followed by discussions, critical evaluation, scientific and practical implications. Finally, the limitations of the study are reflected and possible avenues for further research are indicated.

\section{Theoretical Background and Hypothesis}

Researchers have been making considerable efforts to analyze how the internal organizational context affects individual entrepreneurial behaviour (Zahra et al., 1999). Shepherd and Krueger (2001) pointed out that the internal environment does send signals to potential entrepreneurs, but they are not always clear and straightforward. Researchers argue that organizational structure (Covin and Slevin, 1991), appropriate leadership style and support (Sebora et al., 2010; Kuratko et al., 1990; Stevenson and Jarillo, 1990) are possible determinants affecting entrepreneurial actions (Kantur and Iseri-Say, 2013). Our model identifying key factors of employee's entrepreneurial intentions is illustrated in Figure 1.

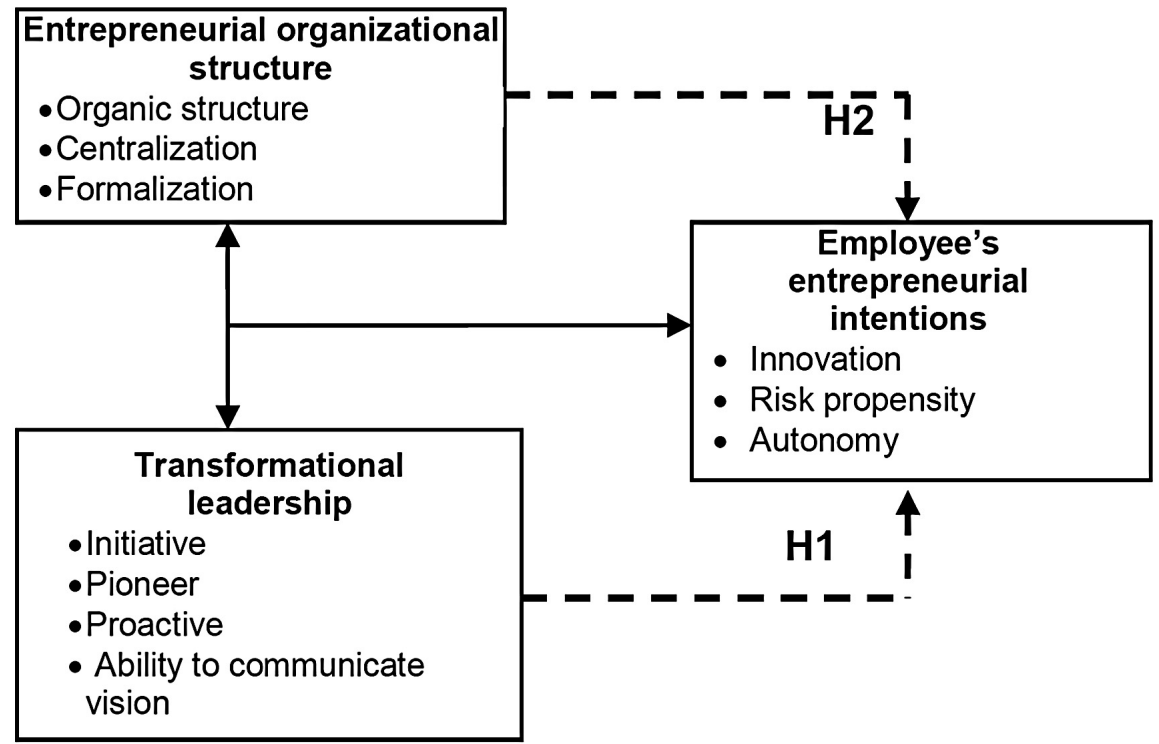

Figure 1: Key factors influencing employee's entrepreneurial intentions - entrepreneurial leadership and entrepreneurial organization structure 
Numerous researchers have embraced an approach analyzing entrepreneurial activities, measured on a scale ranking the companies as more or less entrepreneurial, depending on innovation, risk propensity and proactive behaviour of employees (Covin \& Slevin, 1989; Miller, 1983). In this paper we adopt this scale to analyze employees' entrepreneurial intentions. Innovativeness reflects the willingness of the organization to make a detour from the existing practices and support the development of new ideas, experimentation and creative processes that might lead to new products, services or technology improvements. Until recently, the focus was mainly on technology innovation and advanced production processes, while more recently increased attention is paid to other types of innovation, as well. One of the main factors distinguishing entrepreneurs from other employees in organization is willingness to take chance. Risk propensity is traditionally attributed to individuals, not to organizations. It refers to the extent to which a person is willing to take a chance with respect to possible loss. The result is frequently the discrepancy between individual employees willing to risk and resistant organization, and vice versa, risk-taking organizations with individuals unwilling to step out of the comfort zone (Lumpkin \& Dess, 1996). Autonomy provides the freedom, flexibility and opportunity to initiate entrepreneurial activities (Lumpkin et al., 2009). This is paramount for taking advantage of unutilized potentials of the organization, identifying opportunities outside the core competence and new venture development. Entrepreneurial initiatives are frequently driven by employees acting autonomously in relation to the formal subordination system, often positioned on lower levels of hierarchy. They represent new energy and provide fresh impetus by problem solving beyond the cognitive and organizational patterns. In the following sections we elaborate how entrepreneurial leadership and organization structure influence employee's entrepreneurial intentions.

\subsection{Entrepreneurial leadership}

Entrepreneurial leadership demonstrates the ability to influence others to strategically manage resources in order to encourage a quest for opportunities and sources of competitiveness (Covin and Slevin, 2002). The entrepreneurial leader must convince the followers that entrepreneurship is an integral part of organizational values and the responsibility of every employee. It helps in motivating potential entrepreneurs, providing support in innovation development and securing the necessary resources (Hornsby, Naffziger, Kuratko and Montagno, 1993).

An organization managed by an entrepreneurial leader is more likely to be engaged in stimulating and encouraging employees' entrepreneurial intentions (Ling et al., 2008). Entrepreneurial leadership is defined primarily in terms of the leader's effect on followers, and the behaviour used to achieve this effect (Bass and Avolio, 1995). Entrepreneurial leaders offer a purpose transcending short-term goals; they appear as visionary and inspiring figures, motivating, assembling teams, providing recognition and guidance. They inspire trust, admiration, loyalty and respect, motivating their followers to engage beyond expectations. By questioning the existing organizational processes and structure, they shape the behaviour of the first-level managers in terms of their risk propensity, influencing the overall corporate entrepreneurial efforts (Ling et al., 2008). Entrepreneurial leadership in the form of inspiring and stimulating employees has a significant positive impact on employee attitudes to changes (Babic et al., 2014). Entrepreneurial leaders influence their subordinates raising awareness of the importance of change, encouraging them to align personal and organizational goals and activate higher-order needs (self-respect, success, promotion, etc.). Entrepreneurial leaders influence others to manage resources strategically in order to emphasize both opportunity-seeking and advantage-seeking behaviours (Fernald et al., 2005, Covin and Slevin, 2002). The leader is capable of anticipating and envisioning the future; he is flexible, having strategic orientation and collaboration with employees, aiming to initiate change that will ensure competitiveness (Kuratko and Audretsch, 2009). Managers with leadership capabilities have a key role in organizational learning, and in general, internal knowledge transfers (Petkovic, Aleksic Miric, \& Bozinovic, 2011). The leader's responsibility is to convince others that entrepreneurial activities represent an integral part of the dominant value system and that all employees are responsible for their implementation. He provides guidance and motivation for potential entrepreneurs, refining entrepreneurial ideas and obtaining the necessary resources (Hornsby et al., 1993). When the top management clearly communicates an entrepreneurial strategic vision, employees will have more audacity, orientation and moral justification to behave in an entrepreneurial manner (Ireland et al., 2009).

Recent research studies focused on the leader's cognitive factors (Alvarez and Barney 2007; Hayton and Kelley 2006; Antoncic and Hisrich 2003; Wright et al., 2000;) influencing the employee's entrepreneurial intentions. Entrepreneurial leaders demonstrating initiative, pushing change, and focusing on positive outcomes have a higher influence on employees. They are better equipped to start and implement changes, and less prone to discouragement and suspicion. Hope, optimism and flexibility are often referred to in the literature as key prerequisites for the emergence of entrepreneurial leadership (Peterson, Walumbwa, Byron, \& My- 
rovitz 2009). Entrepreneurial leaders are pioneers, motivating and inspiring employees to adapt, by exhibiting emotional intelligence, self-consciousness, self-control and social skills (Grant, 2009: 458-460). They demonstrate self-confidence and gain the trust and affection of employees, manifesting an idealized influence and inspirational motivation. Employees perceive them as visionary and are willing to follow by expressing entrepreneurial intentions. Thanks to positive attitude and unquestionable moral compass, they take proactive approach, keep moving forward, regardless of the challenges they might face. They strive to encourage risk-taking, creativity and innovation by adjusting leadership style depending on circumstances. Optimistic leaders communicate a clear vision, strengthening the faith of the employees and the persuasion that change is not only possible but necessary along the way. Even under high levels of stress, they will remain steadfast, enthusiastic and willing to act. Leaders encourage followers to be creative and innovate by providing intellectual stimulation and inspiration.

Hypothesis 1. Entrepreneurial leadership style has a positive influence on employees' entrepreneurial intentions.

\subsection{Entrepreneurial organizational structure}

Numerous studies have been conducted regarding organizational conditions favourable for encouraging entrepreneurial initiative, especially in the context of designing an adequate organizational structure (e.g. Hisrich et al., 2008: 75- 77; Hornsby et al., 1993; Zahra, 1991; Guth and Ginsberg, 1990; Sathe, 1989; Burgelman, 1984). Organizational structure is the formal pattern of how jobs are allocated to people and divisions, how the communication flow is structured and how the hierarchical relationships between people are made (Noorderhaven, 1995). The organizational structure of new venture is dynamic and flexible, but in time, as an organization grows, it is getting more and more rigid and bureaucratic, restraining creativity and entrepreneurial initiative.

Organizational structures are not equally capable of supporting the employees' innovative behaviour. The requirements of entrepreneurial organizations are not conducive to traditional structures, predominantly inclined towards short term exploitation, neglecting long-term competitiveness. Designing an "idea/" organizational structure, friendly to entrepreneurial initiatives and actions involves a sequence of decisions, referring to defining clear vision and strategic direction, levels of specialization, departmentalization, coordination, the span of control, decentralized authority, and communication (Zur and Walega, 2015). Daft and Levin (1993) argue that rapid changes in technology and necessity of encouraging entrepreneurial initiative in organizations means that they should be characterized by "flatter hierarchies, decentralized decision-making, a greater tolerance of ambiguity, permeable internal and external boundaries, empowerment of employees, capacity for renewal, self-organizing units and self-integrating coordination mechanisms". In a flat organizational structure cross-functional collaboration and interactions are priorities, the span of control is broad, and number of hierarchical levels is limited. It is noted that a more flexible organizational design embodied in contemporary organization structures, provide more space for the promotion of entrepreneurial behaviour (Dess et al., 1999).

Organizational structures can be classified as follows (Miller, 1996): simple structure - centralized authority, low specialization and formalization, coordination through direct monitoring, innovation depending on the leader's knowledge and awareness; mechanistic bureaucracy - a strong hierarchy and bureaucracy, high centralization and formalization, coordination through standardization, technology automated and integrated, internally oriented information system; organic structure - a highly flexible structure, hierarchy is not emphasized, few bureaucratic rules and procedures, cross-functional collaboration is encouraged for designing and developing complex products with a short lifecycle, an adjustable externally oriented information system, emphasized interpersonal relations and communication, decentralized authority, based on expertise (Miller, 1983); division structure - product/market oriented divisions as separate profit centres often have an organic structure, authority is delegated to division managers, constant pressure towards formalization, entrepreneurial intensity varies, over time divisions become more bureaucratic and autonomous. Divisions are mainly focused on incremental innovation; therefore, corporate entrepreneurship is at a low or medium level (Besanko et al., 2004: 543-545).

Organic structure, the most adequate for encouraging entrepreneurial intentions, implies decentralized authority, based on expertise, and a high level of interaction between employees, where coordination is mainly exercised through lateral communication, without filtering information. This is a non-bureaucratic organization, with low specialization and flexible grouping of units, with a broad span of control. Unstructured and innovative problem solving as building bricks of entrepreneurship, are not in compliance with strong cen- 
tralization, typical for traditional organizational structures, where creative thinking and seeking alternative ways is discouraged, resulting in employees resistant to change. Standardized activities such as employee' wage, accounting, taxation and procurement can be organized according to bureaucratic procedures, but new product development, marketing and strategic planning require a more flexible organic structure (Grant, 2009: 182-183). In an organic structure hierarchy is not emphasized, authority decentralization positively affects the knowledge management process in general, ideas flow through normal communication channels, creating internal environment favourable for employees' entrepreneurial intentions.

Organic structure, with low formalization, few rules and procedures, tends to make people feel more relaxed as it opens opportunities for mutual knowledge exchange, thus creating a higher level of creativity and willingness to demonstrate entrepreneurial initiative (Eric Nielsen, Stojanovic-Aleksic, \& Zlatanovic, 2019). High formalization not only fails to ensure an unrestricted flow of knowledge but can also hinder the development of new ideas. Cross-functional collaboration, characteristic for organic structure, is encouraged, especially in designing and developing complex products with a short lifecycle. Highly specialized, routine and repetitive activities of employees are in most cases very formalized, restrained by numerous rules and procedures. This is not a favourable environment for individual entrepreneurial initiative; on the contrary, any independent action might be strongly discouraged. Formalization is therefore in inverse correlation with creativity and innovation, but also with hierarchy level, indicating that middle and top management structures are having more maneuvering space to encourage individual initiative and backup good ideas.

Hypothesis 2. Organic organizational structure, decentralization and low formalization have a positive influence on employees' entrepreneurial intentions.

\section{Research Design}

Data were collected through field research from a random sample of 208 respondents from 19 companies operating in Central Serbia. The companies in the sample operated in a diverse range of industries, including car manufacturing, insurance, food processing and packaging solutions, and pharmaceutical/healthcare production. No single industry is represented in the sample with a proportion higher than $21 \%$. Companies selected for the study were required to be at least two years old and to rely on product or service innovation for survival. Participating and non-participating companies showed no significant differences in terms of size as measured by the number of employees. A five-point Likert scale was used, with respondents ticking the fields to denote the extent to which they (dis)agree with each affirmatively defined statement. The questionnaire was pre-tested to find the average completion time. Overall, the response rate was $27.89 \%$, which is comparable with other similar studies.

The sample is structured as follows: males $66.7 \%$ (130 respondents), females $33.3 \%$ (65 respondents). For 13 respondents, no data was available. The most numerous respondents were in the 36-45 years age group (39.9\%), followed by those of $26-35$ years $(38.4 \%), 46-55$ years $(15.2 \%), 18-25$ years $(4 \%)$, and more than 56 years $(2.5 \%)$ of age. In total, 163 respondents $(82.3 \%)$ were younger than 46 . Regarding educational level, the majority of the respondents have a university degree $(54.8 \%)$, college or vocational education (17.1\%), which in total forms the majority of the sample (71.9\%). Respondents with 6-15 (39.0\%) and 3-5 (20.5\%) years of work experience dominate. 22 respondents (11.0\%) have less than 2 years and only $10(5 \%)$ have more than 30 years of work experience. Respondents are engaged in various jobs: 50 in manufacturing (28.2\%), 24 in finance and accounting (13.6\%), 23 in logistics and distribution (13.0\%), 21 in marketing and sales (11.9\%), 20 in technical support (11.3\%), 12 in procurement $(6.8 \%)$, and $7(4.0 \%)$ in maintenance and R\&D units. Eight respondents (4.5\%) have other responsibilities, as well. The sample includes 52 managers at all levels: 9 seniors (17.3\%), 31 middle (59.6\%) and 12 supervisors (23.1\%). In total, 47 managers are highly educated $(90.4 \%)$ and 43 are $26-45$ years old.

In our research, we use previously developed and validated measurements, innovation, risk taking and proactiveness (autonomy). The measures have been used for more than three decades for measuring entrepreneurial activities within established organizations (Zahra, 1991, 1996; Covin \& Slevin, 1989, 1991; Guth \& Ginsberg, 1990; Miller, 1983). The complete questionnaire is provided in Table 1. 
Table 1: Questionnaire

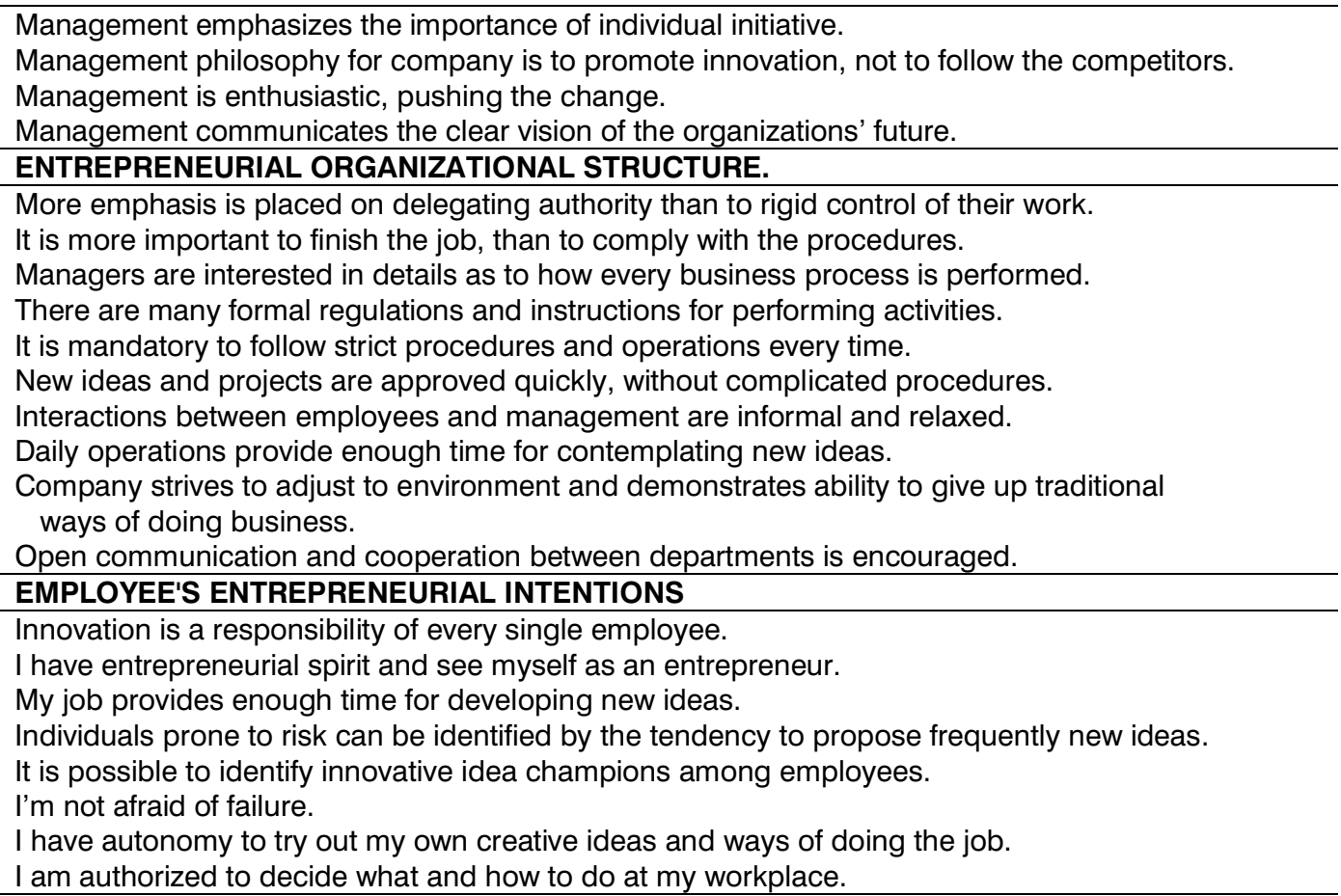

The analysis showed that there are no statistically significant differences in the analyzed variables between companies who did and those who did not take part in the study.

\section{Results}

In this section, we present our findings concerning the key study variables. The reliability of the scale was measured by Cronbach's Alpha coefficient $(=0.868)$. As the minimum threshold for this ratio is 0.7 , the questionnaire is reliable as a measuring instrument and the variables used for measurement are internally consistent (Nunnally, 1978). Descriptive statistic is presented in Table 2.

Table 2: Descriptive statistics for key study variables

\begin{tabular}{lcc}
\hline VARIABLES & $\mathbf{M}$ & $\mathbf{S D}$ \\
\hline Initiative & 3.83 & 1.05 \\
Pioneer & 3.37 & 1.19 \\
Proactive & 3.80 & 1.04 \\
Communicate vision & 3.53 & 1.08 \\
Organic design & 3.50 & .74 \\
Centralization & 3.08 & 1.21 \\
Formalization & 3.00 & .69 \\
Innovation & 3.60 & .71 \\
Risk propensity & 3.60 & .68 \\
Autonomy & 3.28 & 1.05 \\
\hline
\end{tabular}

Correlation analysis has been used to identify and quantify the strength of the relationship between the analyzed variables. We are drawing conclusions using Pearson's coefficient $(r)$ by setting an appropriate significance level $(p<0.05 ; p<0.01)$ (Table 3). 
Table 3: Correlations among key study variables

\begin{tabular}{|c|c|c|c|c|c|c|c|}
\hline & \multicolumn{4}{|c|}{ ENTREPERENEURIAL LEADERSHIP } & \multicolumn{3}{|c|}{ ORGANIZATIONAL STRUCTURE } \\
\hline VARIABLES & Initiative & Pioneer & Proactive & $\begin{array}{c}\text { Communicate } \\
\text { vision }\end{array}$ & Formalization & Centralization & $\begin{array}{c}\text { Organic } \\
\text { design }\end{array}$ \\
\hline Innovation & $.206^{\star *}$ & $.167^{*}$ & $.225^{\star *}$ & .121 & $.317^{* *}$ & $.188^{\star *}$ & $.546^{\star *}$ \\
\hline $\begin{array}{l}\text { Risk } \\
\text { propensity }\end{array}$ & .065 & .099 & .103 & .043 & .096 & .032 & $.142^{*}$ \\
\hline Autonomy & $.172^{*}$ & .105 & $.175^{*}$ & $.159^{*}$ & $.305^{\star *}$ & $.364^{\star \star}$ & $.391^{* *}$ \\
\hline
\end{tabular}

**. Correlation is significant at the 0.01 level (2-tailed).

*. Correlation is significant at the 0.05 level (2-tailed).

The regression model has been used to analyze the influence of leadership style and organizational structure on employees' entrepreneurial intentions (innovation, risk propensity, and autonomy). The regression model results are presented in Table 4 for entrepreneurial leadership as a predictor of employees' entrepreneurial intentions.

Table 4: Entrepreneurial leadership as predictor of employees' entrepreneurial intentions

\begin{tabular}{lccccccccc}
\hline \multirow{2}{*}{ VARIABLES } & \multicolumn{3}{c}{ Innovation } & \multicolumn{3}{c}{ Risk propensity } & \multicolumn{3}{c}{ Autonomy } \\
& $\beta(p)$ & $R^{2}$ & $\beta(p)$ & $\beta(p)$ & $R^{2}$ & $\mathrm{~F}$ & $\beta(p)$ & $R^{2}$ & $\mathrm{~F}$ \\
\hline Initiative & $.206^{\star}$ & .038 & $.172^{\star}$ & 0.065 & .004 & .837 & $.172^{\star}$ & .025 & $6.149^{\star}$ \\
Pioneer & $.167^{\star}$ & .023 & .105 & 0.099 & .005 & 1.917 & .105 & .006 & 2.17 \\
Proactive & $.225^{\star \star}$ & .046 & $.175^{\star}$ & 0.103 & .006 & 2.118 & $.175^{\star}$ & .026 & $6.32^{\star}$ \\
Communicate vision & 0.121 & .010 & $.159^{\star}$ & 0.043 & .002 & .361 & $.159^{\star}$ & .020 & $5.19^{\star}$ \\
\hline
\end{tabular}

* probability level p 0,05; ** probability level p 0,01

standardized regression coefficients are reported; all tests are two tailed

The above procedure was repeated to test the organizational structure as a predictor of the employees' entrepreneurial intentions (Table 5).

Table 5: Organizational structure characteristics as predictor of employees' entrepreneurial intentions

\begin{tabular}{|c|c|c|c|c|c|c|c|c|c|}
\hline \multirow{2}{*}{ VARIABLES } & \multicolumn{3}{|c|}{ Innovation } & \multicolumn{3}{|c|}{ Risk propensity } & \multicolumn{3}{|c|}{ Autonomy } \\
\hline & $\beta(p)$ & $R^{2}$ & $\mathrm{~F}$ & $\beta(p)$ & $R^{2}$ & $\mathrm{~F}$ & $\beta(p)$ & $R^{2}$ & $\mathrm{~F}$ \\
\hline Formalization & $.317^{\star \star}$ & .096 & $22.5^{\star}$ & 0.096 & .004 & 1.85 & $.305^{\star \star}$ & .088 & $20.50^{\star \star}$ \\
\hline Centralization & $.188^{*}$ & .031 & $7.48^{*}$ & 0.032 & .001 & .210 & $.364^{\star *}$ & .128 & $30.86^{\star *}$ \\
\hline Organic organizational design & $.546 * *$ & .295 & $84.96^{*}$ & $.142 *$ & .015 & $4.03^{*}$ & $.391^{\star *}$ & .149 & $35.77^{* *}$ \\
\hline
\end{tabular}

* probability level p 0,05; ** probability level p 0,01

standardized regression coefficients are reported; all tests are two tailed

\section{Discussions and Contributions}

The subtle signals the management is transferring to employees have a strong impact on their behaviour. Analyzing the relevance of an entrepreneurial leadership style for employees' entrepreneurial intentions, employees consider leaders' initiative and pioneering to be the most important ones (Table 3). There is a statistically significant moderate positive correlation between the variables of entrepreneurial leadership, pioneer $(r=0.167, p<0.05)$, proactive $(r=0.225, p<0.01)$, initiative $(r=0.206, p<0.01)$ and the employees' intentions to innovate through entrepreneurial actions. We identified a positive correlation between the variables of entrepreneurial leadership: proactive behaviour $(r=0.175, p<0.05)$, initiative $(r=0.172, p<0.05)$, communicating vision $(r=0.159, p<0.05)$ and the employees' intentions to act autonomously. Employees generally feel that leaders who are willing to act as agents of change, encouraging others to act in the same way, have a significant impact on entrepreneurial intentions and activities. The manager's initiative and encouraging creativeness are powerful instruments of motivating employees. They will be more willing to consider becoming entrepreneurs if the manager is constantly pushing forward, questioning status quo and pivoting the change. The way the leader acts represents a significant signal about employees' preferred ac- 
tivities and behaviour. As noted by Ireland, Covin and Kuratko (2009), when top management clearly promotes an entrepreneurial strategic vision, employees will have more courage, orientation and moral justification to behave entrepreneurially. These findings are consistent with other similar studies too, stressing that there must be a consensus about the dominant logic, implying consent about expectations, signalizing which opportunities are important, which behaviours are appropriate and which results are valuated (Dess, Ireland, Zahra, Floyd, Janney, \& Lane, 2003). The employees' willingness to act autonomously will be affected when the leader demonstrates initiative, proactive behaviour and clearly communicates vision. Autonomy from the entrepreneurial perspective refers primarily to strategic autonomy, enabling operations outside normal organizational constraints. Autonomous strategic behaviour is equivalent to entrepreneurship in organization, as it refers to new combinations of available resources. An entrepreneurial leader must engage more to encourage these efforts, providing more space and allowing potential entrepreneurs to step outside of the given organizational framework and the established norms. Independent thinking and free action are prerequisites for new value creation. Based on the above, hypothesis 1 is partially supported, i.e., an entrepreneurial leadership is positively correlated with employees' entrepreneurial intentions.

Considering identified dimensions of organizational structure, the respondents mostly agree that the organization should lean toward an organic design, while they are more ambiguous when it comes to the degree of centralization and formalization (Table 3). Innovation, autonomy and risk propensity are identified as important aspects of employees' entrepreneurial intentions, thriving in organic organizational structure. The analysis shows that there is a statistically significant positive correlation between organic design $(r=0.546$, $p<0.01)$, centralization $(r=0.188, p<0.01)$ and formalization $(r=0.317, p<0.01)$, and the employees' propensity to innovative entrepreneurial behaviour. We also identified statistically significant positive correlation between organic design $(r=0.391, p<0.01)$, centralization $(r=0.364, p<0.01)$, formalization $(r=0.305, p<0.01)$, and the employees' autonomous behaviour. The regression model results indicate that innovativeness of employees is influenced by leaders' initiative, pioneering, and proactive demeanor. According to the standardized regression coefficient, an organic organizational design is the most significant individual predictor of innovation $(=0.546, p<0.01)$, explaining $29.5 \%$ of the variance employees' entrepreneurial intentions $\left(R^{2}=.295\right)$. Organic organizational design is also the most significant predictor of risk propensity $(=0.142$, $p<0.05)$. The regression model indicates that autonomy is dependent upon all the analyzed variables: the most significant predictor of autonomy is an organic organizational design $(=0.391, p<0.01)$, explaining $14.9 \%$ of the variance, centralization $(=0.364, p<0.01)$ and formalization $(=0.305, p<0.01)$, respectively. The employee's innovative intentions are influenced by an organic organizational design, level of formalization and centralization. Low centralization implicates high decentralization. Employees are more likely to become entrepreneurs when the organization is more decentralized, i.e., management is willing to delegate authority and to waive strict control mechanisms. The most influential single variable is an organic organizational design, characterized by open communication channels and limited formalization. Entrepreneurial initiative is compliant with low levels of formalization, when employees are not required to follow the same routines and operating procedures on a daily basis, when new ideas and projects are approved efficiently, without excessive bureaucracy, and interpersonal relations are informal and spontaneous. Employees are more willing to risk and embrace uncertainty when communication is open and internal boundaries more flexible. The findings of this study also indicate that employees are more willing to act autonomously, starting their own venture or project, if they feel empowered by higher managerial levels, not overwhelmed with formalities and procedures, and in general feel positive feedback and encouragement, typical for organic design. Results are aligned with other similar studies (Burns, 2010: 482-499, Grant, 2009: 182-183). Based on the above, we found evidence that an organic organizational structure, decentralization and low formalization have a positive influence on employees' entrepreneurial intentions, thus hypothesis 2 is supported.

This study makes a scientific contribution to the literature in several ways. First, the results shed more light on the organizational dynamics related to entrepreneurial activities of employees, from a theoretical point of view. Second, the survey revealed new facts about the relevance of both the leadership style and the organizational structure, for creating a favorable environment for entrepreneurial actions. More specifically, it attempts to clarify the relevance of leaders' influence on employees' innovativeness and readiness to act autonomously. Analysis also provides a more fine-grained perspective of organic organizational design as most suitable for encouraging entrepreneurial intentions of employees. Third, study contributes by linking innovative and autonomous actions of employees with leadership based on proactive behaviour and initiative. Fourth, the paper improves understanding of the employees' actions depending on authority delegation, rules and overall flexibility of organizational structure.

The practical implications represent guidelines for managers and practitioners how to set up internal environment favourable for fostering entrepreneurship among employees. First, managers need to understand that the standpoint they take and the support they provide is crucial in encouraging employees' entrepre- 
neurial intentions. Second, they should be informed how important it is to align leadership style in a way that promotes innovativeness and individual initiative of creative individuals. Third, managers should be aware that an organic organizational design is best suited for promoting entrepreneurship because the nature of communication makes employees feel free to express themselves and initiate the change.

Conclusion

The limitation of this study lies in its inability to keep track of entrepreneurial activities in organizations over time. The research is implicitly based on the assumption that the structure and leadership style are relatively static factors. However, it is necessary to analyze how they evolve, as well as the relation of these changes to entrepreneurial behaviour, and this is almost impossible without a longitudinal approach.

How to reinforce and make a traditional organization more flexible and efficient through entrepreneurial initiative as a mean of sustainable competitive advantage remain the most promising field and the ultimate challenge for researchers in the future. The findings suggest that more in-depth research on this issue is necessary and new research avenues should be pursued, referring to other relevant preconditions of employees' entrepreneurial intentions, such as organizational processes, knowledge management and strategic approach to entrepreneurship. We hope our study will inspire further examination of this complex yet promising topic.

\section{REFERENCES}

[1] Alvarez, A. S. \& Barney, J. B. (2007). Discovery and creation: Alternative theories of entrepreneurial action. Strategic Entrepreneurship, 1(1/2), 11-26. DOI: 10.1002/sej.4

[2] Antoncic, B. \& Hisrich, R. D. (2003). Clarifying the intrapreneurship concept. Journal of Small Business and Enterprise Development, 10(1), 7-24. DOI: 10.1108/14626000310461187

[3] Babic, V., Savovic, S., \& Domanovic, V. (2014). Transformational leadership and post-acquisition performance in transitional economies. Journal of Organizational Change Management, 27(6), 856-876. DOI: $10.1108 / J O C M-02-2014-0028$

[4] Bass, B. M., \& Avolio, B. J. (1995). The multifactor leadership questionnaire. Palo Alto, CA: Mind Garden.

[5] Besanko, D., Dranove, D., Shanley, M., \& Schaefer, S. (2004). Economics of strategy, $3^{\text {rd }}$ ed., New Jersey, John Wiley \& Sons, Inc.

[6] Bhattacharyya, S. (2006). Entrepreneurship and innovation: how leadership style makes the difference. The Journal of Decision Makers, 31(1), 107-115. DOI: 10.1177/0256090920060109

[7] Burgelman, R. A. (1984). Designs for corporate entrepreneurship in established firms. California Management Review, 26(3), 154-166. DOI: 10.2307/41165086

[8] Burns, P. (2010). Entrepreneurship and Small Business: Start-up. Growth and Maturity. Palgrave Macmillan International Higher Education, New York.

[9] Covin, J. G. \& Slevin, D. P. (1989). Strategic management of small firms in hostile and benign environments. Strategic Management Journal, 10(1), 75-87. DOI: 10.1002/smj.4250100107

[10] Covin, J. G. \& Slevin, D. P. (1991) A conceptual model of entrepreneurship as firm behaviour. Entrepreneurship Theory and Practice, 16(1), 7-24. DOI: $10.1177 / 104225879101600102$

[11] Covin, J. G. \& Slevin, D. P. (2002). The entrepreneurial imperatives of strategic leadership. In M. A. Hitt, R. D. Ireland, S. M. Camp, \& D. L. Sexton (Eds.), Strategic entrepreneurship: Creating a new mind-set (309-327), Oxford, Blackwell Publishers. DOI: 10.1002/9781405164085.ch14

[12] Daft, R. \& Levin, A. (1993). Where are the theories for the new organizational form? Organization Science, 4(4), 1-6. www.jstor.org/stable/2635077.

[13] Dess, G. G., Ireland, R. D., Zahra, S. A., Floyd, S. W., Janney, J. J., \& Lane, P. J. (2003). Emerging issues in corporate entrepreneurship. Journal of Management, 29(3), 351-378. DOI: 10.1016/S01492063(03)00015-1

[14] Dess, G. G., Lumpkin, G. T., \& McGee, J. E. (1999). Linking corporate entrepreneurship to strategy, structure and process: Suggested research directions. Entrepreneurship Theory \& Practice, 23(3), 85102. DOI: $10.1177 / 104225879902300306$

[15] Eric Nielsen, J., Stojanovic-Aleksic, V., \& Zlatanovic, D. (2019). The Challenges of Managing the Entrepreneurial Organization. Ekonomika, 65(2), 87-98. DOI:10.5937/ekonomika1902087E

[16] Fernald, L.W., Solomon, G.T., \& Tarabishy, A. (2005). A New Paradigm: Entrepreneurial Leadership. Southern Business Review, 30(2), 1-10.

[17] Goffin, K. \& Mitchell, R. (2010). Innovation management, $2^{\text {nd }}$ ed., UK: Palgrave Macmillan.

[18] Grant, M. R. (2009). Contemporary Strategy Analysis, 6 $6^{\text {th }}$ ed., Oxford, UK: Blackwell Publishing. 
[19] Guth, W. D. \& Ginsberg, A. (1990). Corporate Entrepreneurship. Strategic Management Journal, Special issue 11, 297-308. www.jstor.org/stable/2486666.

[20] Hayton, J. C. \& Kelley, D. J. (2006). A competency-based framework for promoting corporate entrepreneurship. Human Resource Management, 45(3), 407-427. DOI: 10.1002/hrm.20118

[21] Hisrich, R. D., Peters, M. P., \& Shepherd, D. A. (2008). Entrepreneurship, $7^{\text {th }}$ ed., New York, NY: McGrawHill.

[22] Hornsby, J. S., Naffziger, D. W., Kuratko, D. F., \& Montagno, R. V. (1993). An interactive model of the corporate entrepreneurship process. Entrepreneurship Theory and Practice, 17(2), 29-37. DOI: $10.1177 / 104225879301700203$

[23] Ireland, R. D., Covin, J. G., \& Kuratko, D. F. (2009). Conceptualizing corporate entrepreneurship strategy. Entrepreneurship Theory \& Practice, 33(1), 19-46. DOI: 10.1111/j.1540-6520.2008.00279.x

[24] Kantur, D. \& Iseri-Say, A. (2013). Organizational context and firm-level entrepreneurship: a multiple-case analysis. Journal of Organizational Change Management, 26(2), 305 - 325.

[25] Kelley, D. (2011). Sustainable corporate entrepreneurship: evolving and connecting with the organization. Business Horizons, 54(1), 73-83. DOI: 10.1108/09534811311328362

[26] Kuratko, D. \& Audretsch, D. (2009). Strategic entrepreneurship: exploring different perspectives of an emerging concept. Entrepreneurship Theory and Practice, 33(1), 1-17. DOI: 10.1111/j.15406520.2008.00278.x

[27] Kuratko, D. F., Montagno, R. V., \& Hornsby, J. S. (1990). Developing an entrepreneurial assessment instrument for an effective corporate entrepreneurial environment. Strategic Management Journal, 11(1), 49-58. www.jstor.org/stable/2486669.

[28] Ling, Y., Simsek, Z., Lubatkin, M. H., \& Veiga, J. F. (2008). Transformational leadership's role in promoting corporate entrepreneurship: Examining the CEO-TMT interface. Academy of Management Journal, 51(3), 557-576. DOI: 10.5465/AMJ.2008.32626023

[29] Lumpkin, G. T., Cogliser, C. \& Schneider, D. R. (2009). Understanding and measuring autonomy: An entrepreneurial orientation perspective. Entrepreneurship Theory and Practice, 33(1), 47-69. DOI: 10.1111/j.1540-6520.2008.00280.x

[30] Lumpkin, G.T. \& Dess, G.G. (1996). Clarifying the entrepreneurship orientation construct and linking it to performance. Academy of Management Review, 21, 135-172. DOI: 10.2307/258632

[31] Martin-Rojas, R., Garcia-Morales, V. J., \& Mihi-Ramirez, A. (2011). How can we increase Spanish technology firm's performance. Journal of Knowledge Management, 15(5), 759-778. DOI: $10.1108 / 13673271111174311$

[32] Miller, D. (1983). The correlates of entrepreneurship in three types of firms. Management Science, 29(7), 770-791. DOI: $10.1287 / \mathrm{mnsc} .29 .7 .770$

[33] Miller, D. (1996). Configurations revisited. Strategic Management Journal, 17(7), 505-512. DOI: 10.1002/(SICI)1097-0266(199607)17:7\%3C505::AID-SMJ852\%3E3.0.CO;2-I

[34] Noorderhaven, N. G. (1995). Strategic Decision Making. Wokingham: Addison-Wesley.

[35] Nunnally, J.C. (1978). Introduction to Psychological Measurement. New York: McGraw-Hill.

[36] Peterson, S. J., Walumbwa, F. O., Byron, K., \& Myrovitz, J. (2009). CEO Positive psychological traits, transformational leadership and firm performance in high-technology start-up and established firms. Journal of Management, 35(2), 348-368. DOI: 10.1177/0149206307312512

[37] Petkovic, M., Aleksic Miric, A., \& Bozinovic, I. (2011). Korporatvno liderstvo i menadžment znanja. Sociologija, 53(1), 1-20. DOI: 10.1515/eoik-2015-0012

[38] Sathe, V. (1989). Fostering entrepreneurship in large diversified firm. Organizational Dynamics, 18(1), 2032. DOI: 10.1016/0090-2616(89)90029-6

[39] Sebora, T. C., Theerapatvong, T., \& Lee, S. M. (2010). Corporate entrepreneurship in the face of changing competition: a case analysis of six Thai manufacturing firms. Journal of Organizational Change Management, 23(4), 453-470. DOI: 10.1108/09534811011055421

[40] Shepherd, D. A. \& Krueger, N. F. (2001). An intension-based model of entrepreneurial teams' social cognition. Entrepreneurship Theory \& Practice, 27(2), 221-243. DOI: 10.1111/1540-8520.00005

[41] Srivastava, N. \& Agrawal, A. (2010). Factors supporting corporate entrepreneurship: an exploratory study. The Journal of Business Perspective, 14(3), 163-171. DOI: 10.1177/097226291001400302

[42] Stevenson, H. H. \& Jarillo, C. J. (1990). A paradigm of entrepreneurship: entrepreneurial management. Strategic Management Journal, 11(5), 17-27. DOI:10.1007/978-3-540-48543-8_7

[43] Wright, M., Hoskisson, R., \& Busenitz, L. (2000). Entrepreneurial growth through privatization: The upside of management buy-outs. Academy of Management Review, 25(3), 591-601. DOI: 10.2307/259312

[44] Zahra, S. A. (1991). Predictors and financial outcomes of corporate entrepreneurship: An exploratory study. Journal of Business Venturing, 6(4), 259-285. DOI: 10.1016/0883-9026(91)90019-A

[45] Zahra, S. A. (1996). Governance, ownership, and corporate entrepreneurship: The moderating impact of industry technological opportunities. Academy of Management Journal, 39(6), 1713-1735. DOI: $10.5465 / 257076$ 
[46] Zahra, S. A., Jennings, D. F., \& Kuratko, D. F. (1999). The antecedents and consequences of firm-level entrepreneurship: The state of the field. Entrepreneurship Theory \& Practice, 24(2), 45-65. DOI: $10.1177 / 104225879902400205$

[47] Zur, A. \& Walega, A. (2015). Routines do matter: role of internal communication in firm-level entrepreneurship. Baltic Journal of Management, 10(1), 119-139. DOI: 10.1108/BJM-11-2013-0166

Received: 2019-03-26

Revisions requested: 2019-07-08

Revised: 2019-09-20 (2 times)

Accepted: 2019-09-23

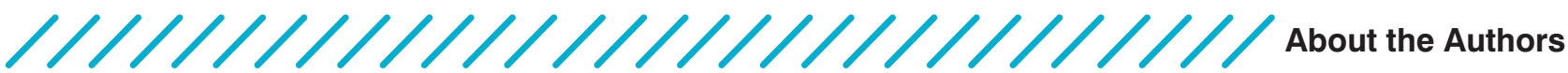

\author{
Jelena Erić Nielsen \\ University of Kragujevac, Faculty of Economics, Serbia \\ jelena_eric@kg.ac.rs
}

Jelena Erić Nielsen received her PhD at the University of Kragujevac, Faculty of Economics, Serbia, where she works as Assistant Professor. Her current research interests include entrepreneurship, corporate entrepreneurship, leadership, organizational behaviour and corporate governance. She has published articles mainly in the field of entrepreneurship and leadership.

\section{Verica Babić \\ University of Kragujevac, Faculty of Economics, Serbia vbabic@kg.ac.rs}

Verica Babic is a full professor and head of the Department of Business Administration at the Faculty of Economics University of Kragujevac, Serbia. She teaches courses at undergraduate studies (Introduction to Management and Decision Theory) at the graduate level (Corporate Governance, Public Sector Management) and the PhD level (Corporate Governance Theory). Her current research interests are corporate governance, leadership, entrepreneurship, innovativeness and knowledge management. She is the author and co-author of eight books, and over 80 publications in scientific journals, monographs' chapters, proceedings from international scientific conferences. During her academic career, she was awarded several national and international (Fulbright, Austrian Government, EU) research grants, employing over fifty researches. She was engaged in numerous projects that deal with higher education, innovativeness and entrepreneurship. Currently, she is a coordinator of international research project Innovativeness in Higher Education in Slovenia and Serbia: Comparative Research and Exchange of Good Practices, SL, RS grant.

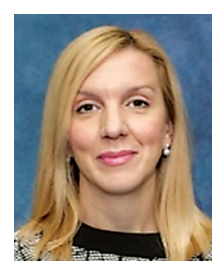

Vesna Stojanović-Aleksić University of Kragujevac, Faculty of Economics, Serbia vesnasa@kg.ac.rs

Vesna Stojanović-Aleksić received her PhD from the University of Kragujevac, Faculty of Economics, Serbia, where she works as Full Professor. Her research interests are related to leadership, organizational culture, organizational theory, organizational behaviour and change. She has published articles mainly in the field of leadership, organizational culture and change.

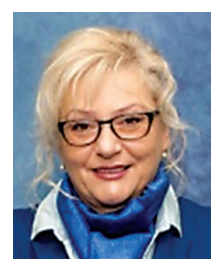

Jelena Nikolić University of Kragujevac, Faculty of Economics, Serbia
jnikolic@kg.ac.rs

Jelena Nikolić is an Assistant Professor on the following subjects: Introduction to Management, Decision Making Theory, Corporate Governance, at the Faculty of Economics, University of Kragujevac, Republic of Serbia. She received her PhD from the University of Kragujevac, Faculty of Economics. Her research focus is on strategic decision making, corporate governance and corporate entrepreneurship. She is the author/co-author of numerous scientific papers and monograph chapters.
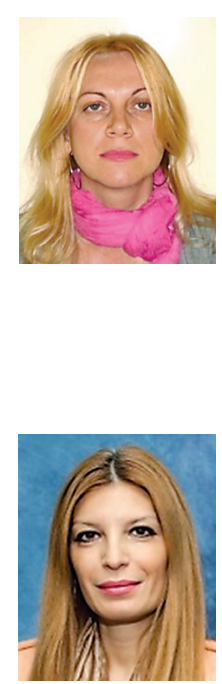